\title{
Evaluation of the Contextual Factors of Puerto Vallarta to Define Graduate Profiles in Higher Education Institutions
}

\section{Evaluación de los Factores Contextuales de Puerto Vallarta para la Definición de Perfiles de Egreso en Instituciones Educativas de Nivel Superior}

\author{
NAVARRO-ALVARADO, Alberto†*, GONZÁLEZ-MORENO, Cynthia Dinorah and SÁNCHEZ- \\ BELTRÁN, Martha Irene
}

Instituto Tecnológico José Mario Molina Pasquel y Henríquez, Campus Puerto Vallarta

ID $1^{\text {st }}$ Author: Alberto, Navarro-Alvarado / Researcher ID Thomson: S-6753-2018, CVU CONACYT ID: 168836

ID $1^{\text {st }}$ Coauthor: Cynthia Dinorah, González-Moreno / Researcher ID Thomson: S-6945-2018, CVU CONACYT ID: 275330

ID $2^{\text {nd }}$ Coauthor: Martha Irene, Sánchez-Beltrán / CVU CONACYT ID: 822137

DOI: $10.35429 / J H R T .2019 .16 .5 .19 .34$

Received: July 30, 2019; Accepted: December 20, 2019

\begin{abstract}
This paper analyzes several factors that constitute the economical and institutional context of the municipal environment of Puerto Vallarta in Jalisco state, focused on detect the needs of professional profiles in higher education institutions. These factors can be considered as a main intervention axis to constitute the regional context, which is crucial to define the desirable professional profiles in higher education graduates. To elaborate the present study various indicators were analyzed, mainly those who are generated by state government offices and some other public dependencies with regional intervention, all of them aligned to evaluate contextual factors thru the identification of a transversal association of the data. We wish to identify the pertinency of the professional profile in the higher education graduates based on the results of the present analysis, furthermore the main tendencies in higher education that can be promoted in local educational offer to generate an appropriate response to actual and future needs thru an objective evaluation of the context that considers the international educational tendencies.
\end{abstract}

Higher education, Higher education graduate profiles, Regional context

\begin{abstract}
Resumen
En el presente documento se analizan diversos factores que conforman el contexto económico e institucional del municipio de Puerto Vallarta, en el estado de Jalisco, enfocado a detectar las necesidades de perfiles de egreso en el nivel superior. Estos factores son observados como ejes fundamentales de intervención para la conformación del contexto regional, el cual es determinante para la definición del perfil al que atienden los egresados de nivel superior. Para llevar a cabo el presente análisis, se revisan diversos indicadores, principalmente, con base en los informes gubernamentales y de otras dependencias públicas que ofrecen información estadística sobre el municipio, así como del estado, para realizar una evaluación del contexto a través de la relación transversal de la información recuperada. Se espera, con base en los resultados obtenidos, identificar la pertinencia de perfiles de egresados de nivel superior a partir de las necesidades regionales, así como las tendencias principales de especialidad que pueden generarse en la oferta educativa de la región para poder responder oportunamente a las necesidades actuales y futuras a través de un diagnóstico objetivo y que considere las principales tendencias internacionales hacia las que se dirige la formación superior.
\end{abstract}

Educación superior, Perfiles de egreso, Contexto regional

Citation: NAVARRO-ALVARADO, Alberto, GONZÁLEZ-MORENO, Cynthia Dinorah and SÁNCHEZ-BELTRÁN, Martha Irene. Evaluation of the Contextual Factors of Puerto Vallarta to Define Graduate Profiles in Higher Education Institutions. Journal of Human Resources Training. 2019, 5-16: 19-34

*Correspondence to Author: alberto.navarro@vallarta.tecmm.edu.mx)

$\dagger$ Researcher contributing first Author 


\section{Introduction}

This study is carried out by the Academic Body in Innovation Management and Technology Transfer in Business Organizations, of the Mario Molina Technological Institute (ITMM), Puerto Vallarta Campus (CPV), with the intention of identifying the key elements, conditions and factors Incidents in the training of students at a higher level in relation to their area of influence in the Engineering in Business Management career offered at this institution.

Derived from the need to update, according to the national reality, the programs, contents and specializing training of future professionals in the management of organizations, this study is developed to offer current and reliable information to generate focused and useful proposals that contribute to fully comply with the institutional objectives proposed by the National Technological Institute of Mexico and, at the same time, meet the present and future needs of business organizations in the area of influence, in strict adherence to the development of the state of Jalisco.

Considering, on the other hand, the global integration that is experienced throughout the national territory, the avant-garde trends are analyzed, as well as the binding factors to the labor insertion of technological training graduates in order to include inclusive, global and global development. social awareness, so this document is not limited to a local environment, but aims to encompass, as far as possible, global trends that strengthen the prominent approaches to the graduation profile projected by the Institute.

The document starts, in a first section, of the diagnosis of the region, which allows starting from the perceptible reality that students face in their training. Here we present information collected by dependencies focused on the generation of constant and updated information in all the dimensions that constitute the social and economic environment of the region, such as the National Institute of Geography and Informatics and the Institute of Statistical and Geographic Information of Jalisco , as well as all the information provided by the Municipal Government and the Government of the State of Jalisco.

\section{Justification}

This document is made with the intention of evaluating the various social, contextual and economic dimensions that are involved for the development of a training specialty in the area of Engineering in Business Management, for the José Mario Molina Pasquel y Henríquez Technological Institute, in your Puerto Vallarta campus.

With the intention of collecting the possible information, various reports issued by the state government were consulted, as well as prestigious agencies dedicated to the generation of updated data in various dimensions, primarily economic, such as the National Institute of Statistics and Geography (INEGI) and the Institute of Statistical and Geographical Information (IIEG).

To complement the data necessary for the development of local and regional analyzes, various information surveys were carried out, such as consultations with specialists, previous diagnoses, surveys of students, graduates and aspiring students for entry to the race based on their profile and preferences.

Some of the official data are not updated, especially because of the periodicity in which they are applied, or because of the changes of certain programs for the generation of information. In this sense, the Government of the State of Jalisco, has recently had international recognition for its work for the generation of information, which offers a framework of interest for the establishment of information systems through the use of Information Technology and Communications that offer updated and constant information.

On the other hand, it should be noted that the prospective analysis is largely shaped by the work agendas presented by the state government, although the aspects that are a concern of international organizations are also integrated, trying to offer a sufficiently comprehensive application scenario. comprehensive that allows to consider the immediate and future needs of higher level academic training. 
Finally, we will mention that this study has been carried out through the constant effort of the Academic Body in Management of Innovation and Technology Transfer in Business Organizations, attached to the ITMM, which emphasizes its efforts to constantly improve and update issues related to the avant-garde research in the field of economic and administrative sciences, so we hope this study will be useful not only for the degree in Engineering in Business Management, but also to offer a cutting-edge panorama on the training needs of our students in in such a way that timely intervention strategies are generated focusing on the great trends identified, namely, inclusion, environmental awareness, preservation of cultural heritage and the integral development of individuals focused on common well-being.

\section{Problematization}

The constant changes in the current environment generate alterations in the way in which educational systems and models are proposed. Probably, the higher level is the most sensitive to these fluctuations, since it makes up the last level of the long formative trajectory that forms the national education system. This educational structure varies according to the needs of the environment of each educational institution, which requires a constant update of the available information available.

Within the technological system, represented by the National Technological Institute of Mexico, which includes the higher education platform of this nature, there are constant updates to its programs and curricula periodically, although the specialties, as the last phase of technological training, present shorter update periods, which offers an important opportunity to generate updated and useful data to recognize the changes that have occurred in the environment and the economic and occupational needs of the regions in question.

In the ITMM-CPV, the periods for the specialty update are close to renewal, so it is considered pertinent to carry out an in-depth study on the most relevant factors that make up the economic, social and, by extension, labor environment, which will allow identify the most relevant derived trends focused on the design of relevant academic proposals for the updating of higher level educational programs.

\section{Hypothesis}

Updates of higher level academic programs in the technological system that are based on up-todate information based on the most relevant influential environmental factors for the training profile improve graduation profiles because they adhere to the real needs of the immediate environment for job placement.

\section{Objective}

The following document is developed based on the following guideline which, in turn, forms the central objective of the research carried out: Evaluate the contextual factors of the Puerto Vallarta region and its geographical area of influence to determine the training needs at the higher level in the region by educational institutions.

\section{Reference Framework}

\section{Regional socio-economic activities by sector}

According to the Government of Jalisco (2019), the municipality of Puerto Vallarta composes its economic activities mainly in the following subsectors:

\begin{tabular}{|l|l|}
\hline \multicolumn{1}{|c|}{$\begin{array}{l}\text { Sector or } \\
\text { subsector }\end{array}$} & $\begin{array}{l}\text { Agriculture consists of crops of corn, } \\
\text { sorghum, beans, zucchini, green chili, tomato, } \\
\text { peanut, sesame, watermelon, tobacco, } \\
\text { avocado, mango and banana. }\end{array}$ \\
\hline $\begin{array}{l}\text { Cattle } \\
\text { raising }\end{array}$ & $\begin{array}{l}\text { Cattle are raised for meat and dairy production } \\
\text { purposes, as well as sheep, pigs, goats and } \\
\text { horses. As well as poultry for meat production } \\
\text { and posture. On a smaller scale there is honey } \\
\text { production. }\end{array}$ \\
\hline Industry & $\begin{array}{l}\text { This is quite limited and is mainly handmade, } \\
\text { such as clothing, huarache shoes and beach } \\
\text { sandals. Some custom furniture is also } \\
\text { produced. }\end{array}$ \\
\hline Commerce & $\begin{array}{l}\text { It consists mainly of necessities, as well as } \\
\text { stores of curiosities, souvenirs, local products } \\
\text { and other similar. }\end{array}$ \\
\hline Services & $\begin{array}{l}\text { The majority of these are concentrated in } \\
\text { tourist activities or derived from them, such as } \\
\text { travel agencies, lodging, food and beverages, } \\
\text { recreation, among others. There are also } \\
\text { associated services, such as maintenance, } \\
\text { professional associations and professional and } \\
\text { technical services. }\end{array}$ \\
\begin{tabular}{|l} 
A limited participation of this subsector in the \\
fishing of dogfish, red snapper, tuna, snapper, \\
smooth, bass, sierra, dorado, shrimp, lobster, \\
oyster and octopus is identified. There is also \\
sport fishing for sailfish (Marlyn).
\end{tabular} \\
\hline
\end{tabular}

Table 1 Description of the main economic activities of Puerto Vallarta, based on sector or subsector Source: Jalisco State Government (2019) 
Based on the information generated in the last National Population and Housing Census (INEGI, 2011), the economically active population in 2010, reached a total of 119,107 people, representing $46.58 \%$ of the population, which represents a consistent increase of $5 \%$ per decade. The economic participation rate also presents an incremental trend, going from $53.96 \%$ in 1990 to $62.5 \%$ for 2010 .

The indicators for the evaluation of occupation and employment are acceptable. Social security services have a record of $97.93 \%$, being among the highest at the state level. The occupational distribution corresponds to the economic distribution (see table 2).

\begin{tabular}{|l|r|}
\hline Occupational Division & \multicolumn{2}{|c|}{$\begin{array}{l}\text { Percentage } \\
\text { distribution }\end{array}$} \\
\hline $\begin{array}{l}\text { Merchants and workers in various } \\
\text { services }\end{array}$ & $50.03 \%$ \\
\hline $\begin{array}{l}\text { Professional, technical and } \\
\text { administrative professionals }\end{array}$ & $29.77 \%$ \\
\hline Industry workers & $17.92 \%$ \\
\hline Agricultural workers & $1.14 \%$ \\
\hline Not specified & $1.14 \%$ \\
\hline
\end{tabular}

Table 2 Percentage distribution of the employed population, according to type of occupation

Source: Jalisco State Government (2019)

The main economic activity of the region is tourism, which suggests a high participation in this economic sub-frame. On the other hand, the municipality presents particular conditions that produce a fundamental differentiation for its economy, such as the proximity to various "Magical Towns", such as Talpa, San Sebastián del Oeste and Mascota, as well as with the Huichol area of Nayarit and Jalisco. Natural factors are added to differentiation, such as islands and non-rocky beaches, ideal for sun and beach destinations (Puerto Vallarta City Council, 2019).

\section{Institutional environment based on economic orientation}

Derived from the relevance that tourism has for the municipality in various fundamental dimensions for its development, such as the economy, culture, education and society, the Jalisco Secretariat of Tourism (SECTURJAL), has a fundamental relevance within the management strategic, as well as lines of action throughout the state, mainly everything related to the use of natural and cultural resources (SECTURJAL, 2019).
The SECTURJAL circumscribes its actions within the regulatory framework established by the Federal Government within the General Tourism Law (DOF 17-12-2015), which establishes that tourism activity must be programmed along with the development of areas with tourist vocation and the improvement of the quality of life of the inhabitants through the coordination of three levels of government, namely federal, state and municipal. Corresponding to the Organic Law of the Federal Public Administration (DOF 12-041976), the General Law of National Assets and the Federal Law on Monuments and Archaeological, Artistic and Historical Sites (DOF 06-05-1972), coordination between dependencies in the three levels of government will serve four main strategic axes:

\section{- $\quad$ Land use planning and transformation \\ - Innovation and competitiveness \\ - $\quad$ Promotion and promotion \\ - $\quad$ Sustainability and social benefits}

In this way, not only public bodies have direct responsibility for the economic development of tourist destinations, but it is expected to have the collaboration of social and private organizations, all this, through the coordination of the institutions empowered by government agencies, as long as they are within the current regulatory framework. According to SECTUR (2014), at the local level, this function, therefore, is the coupling of the economic, educational, cultural and social actions of the tourist areas will be in charge of the Tourism Directorates, who will consider federal regulations and state as well as local regulations. In the case of Puerto Vallarta, public organizations are identified with the provision and exercise of tourism activities, such as the Official Registry of Licensing and Licensing, the Directorate of Social Development, the Directorate of Public Security and the Municipal Tourism Advisory Council, all you are from the conciliation of the Municipal Council of Puerto Vallarta, through its documentation in the Municipal Development Plan.

Regarding the participation of the private sector, there is the participation of the National Chamber of Commerce, Tourism and Services of Puerto Vallarta, which represents the interests of companies in the tertiary sector, offering consulting services aimed at modernization and Competitiveness of small, medium and large businesses within the municipality.

NAVARRO-ALVARADO, Alberto, GONZÁLEZ-MORENO, Cynthia Dinorah and SÁNCHEZ-BELTRÁN, Martha Irene. Evaluation of the Contextual Factors of Puerto Vallarta to Define Graduate Profiles in Higher Education Institutions. Journal of Human Resources Training. 2019 
All this through three main axes of action, these being promotional services, preventive legal assistance and, finally, various aspects of human capital (CANACOSERVYTUR, 2019). The participation of this organization is regional, and its influence is also on the municipalities surrounding Puerto Vallarta, namely Cabo Corrientes, Tomatlán, Talpa de Allende, San Sebastián del Oeste and Mascota.

On the other hand, the Association of Hotels and Motels of Puerto Vallarta, is also identified as a representative organization of collective interests at the regional level, hence it is also called as Association of Hotels and Motels of Puerto Vallarta and Banderas Bay. Its main objective is the inter-institutional link between hotel companies and the various dependencies of the three levels of government, through strategic planning focused on the collaborative management of these units, mainly through organizational and human capital management (Hotel and Motel Association from Puerto Vallarta and Banderas Bay, 2019).

Finally, in relation to the participation of social or non-profit organizations, their activities are potentially lateral with respect to economic activity, however, their participation is highly relevant and has a strong presence in the municipality and its area of influence. In this way, more than forty non-profit organizations that actively participate in the activities of the municipality are identified, which can be classified into three large groups, namely social assistance, which occupies the largest proportion based on organizational units (71 \%), environmental activities focused on the protection of flora and fauna, with $17 \%$ of the total registered organizations, and artistic and leisure activities, with $12 \%$ of the total organizations (see figure 1).
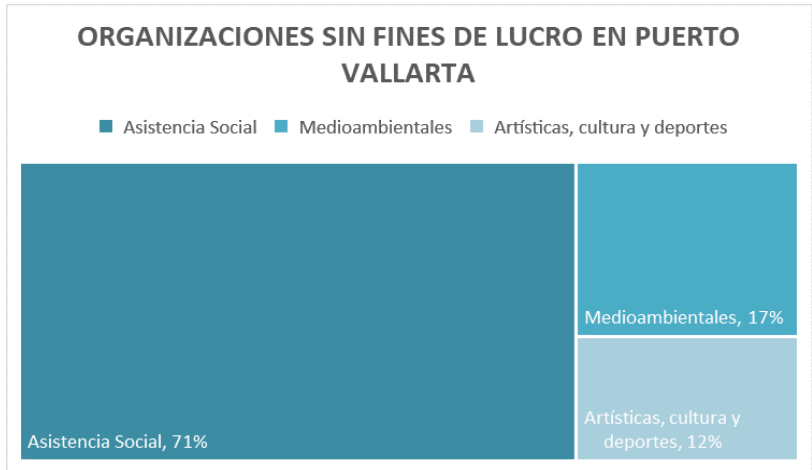

Figure 1 Proportion of non-profit organizations in Puerto Vallarta, JaliscoGrouping and proportional participation of non-governmental organizations based on the number of organisms identified. Source: Own construction based on Altruistic Associations Network and PuertoVallarta.net

\section{Development of institutional and governmental projects}

Puerto Vallarta is classified as one of the main tourist destinations nationwide and is part of the Competitiveness Agendas 2013-2018, so there are various initiatives, projects and inquiries regarding the description and identification of opportunities for strengthening this destination tourist.

The SECTURJAL, presents three studies that have been carried out in the region of Puerto Vallarta focused on the development of proposals based on their results:

Tourism Development Program of the Romantic Zone (of the Historic Center) of Puerto Vallarta. This proposal aims to generate strategies and actions to improve the attractiveness of the geographic area "Historic Center" of Puerto Vallarta through the intervention in four central axes, namely, tourism activity, roads and transport, image and urban development and, finally, the consideration of environmental risks. The reordering of land use, improvement of the urban image and balance of economic activities, all of the above based on a focus on preservation, sustainability and environmental care 
- Competitiveness Plan of Puerto Vallarta as a Cruise Destination. The project aims to specialize and professionalize cruise services through the identification and design of a catalog of consumer products for cruise passengers for Puerto Vallarta. An infrastructure and mobility, competitiveness, positioning and market access program, a product development program at destination, and a program for product launching are established

Lines of Action for the Tourism Planning of the Historic Center of Puerto Vallarta. As a complement to the first proposal, this proposal is based on an approach focused on the improvement of the infrastructure supporting tourist services that integrate urban development plans, mainly in relation to urban transport, improvement of green areas, preservation of historical buildings and urban image improvement

In addition, the Federal Government, through SECTUR and the National Fund for Tourism Promotion, seeks to coordinate the three levels of government through the development of Competitiveness Agendas for Tourist Destinations, integrating the participation of academic institutions to generate proposals focused on solving national problems from the local level. This comprehensive project takes advantage of the use of Information and Communications Technologies, the link between educational, governmental and private units, as well as the fulfillment of the environmental, promotional and information axes through the generation of information resulting from research and development of Projects. From the above, permanent strategic guidelines based on the needs of each of the tourist regions involved are integrated into the Competitiveness Agendas. In the case of Puerto Vallarta, the following guidelines for the formulation of proposals are identified:

\section{From natural and cultural resources}

Natural heritage: it is based on the identification of natural attractions, as well as spaces generated as a result of the preservation of cultural values. It is intended to generate an inventory for its management and preservation of destinations such as, Ánimas, Conchas Chinas, Mismaloya, among many others
- $\quad$ Resources and tourist attractions of the environment: Like the previous point, it is intended to establish an arrangement of natural spaces and cultural populations of interest, so that fundamental elements can be generated for their exploitation and preservation

\section{Diversification of the tourist offer}

- Alternative tourism: It is intended to increase the catalog of tourist products offered, beyond the offer of sun and beach, such as ecotourism, adventure tourism and rural tourism, taking advantage of the geographical advantages of the region, such as the proximity to the Sierra Western mother

- Gay-friendly destination: Based on the economic conformation of its products, Puerto Vallarta is identified in the international context as an important destination for the lesbian-gay-bisexualtransgender (LGBT) market. The segmentation of products offered for this sector reaches $35 \%$ in its various associated products, such as leisure and specialized lodging

- Gastronomic tourism: the region has a wide range of gastronomic products, ranging from local to international dishes, offering a mixed cuisine bar, which is reflected in specialized events, such as the International Gourmet Festival, which is organized from nineteen ninety five

From the complementary offer of tourist services

- $\quad$ Food and beverage services: there are establishments of this branch awarded with the Five Star Dimond and Three Dimonds Award, conferred by the American Academy of Hospitality Sciences, as well as various gastronomic events

- $\quad$ Tourist guides: There are ten tour guides that offer guidance on recreation in the area, which can be used as an efficient means to promote the various existing establishments 
- Museums: the municipality has four museums that are expected to contribute to the promotion and historical preservation. The Puerto Vallarta Naval Historical Museum, the Río Cuale Island Museum, the Regional Museum of Anthropology and the Manuel Lepe gallery museum, are important spaces that have not been fully exploited

Sale of handicrafts: The elaboration of handicrafts on various products offers an important opportunity for professionalization through a mixture of Spanish, Italian, Chinese and indigenous techniques

Business center: the municipality has the International Convention Center, as well as hotels that offer event services, which offers ample opportunities for the organization of congresses, conferences, colloquiums, trainings, conventions, among others

\section{Conditions of regional productive factors}

The production of goods and services in the municipality of Puerto Vallarta is due to an economic structure based on the offer of tourist services and products, so its composition concentrates most of the economic units in the tertiary sector, mainly services, with a $51.8 \%$, followed by trade activities, with $41.8 \%$. The industry, although it registers a positive growth trend in recent years, only agglomerates around $6.4 \%$ of the economic units. On the other hand, the primary activities, such as agriculture and livestock, concentrate less than $1 \%$ (see figure 2).

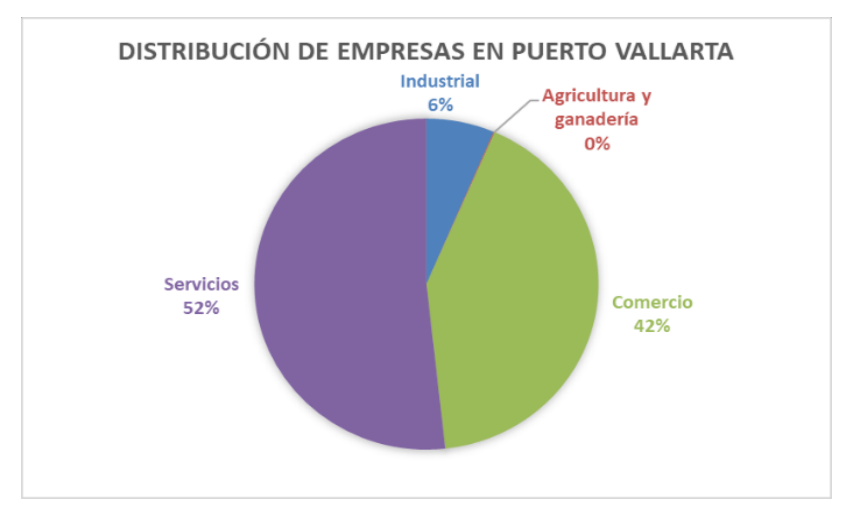

Figure 1 Concentration of companies by sector Grouping of companies in the region based on their main sector

Source: DENUE (2017)
As presented in the Puerto Vallarta Municipal Diagnosis (2018), the main subsectors for the generation of Gross Census Value Added were:

- $\quad$ Temporary accommodation services

- Retail trade in self-service and department stores

- Wholesale of groceries, food, beverages, ice and tobacco

Together, the previous three generate $29.3 \%$ of the total gross census aggregate, according to the latest data from 2014. Comparatively, since the last data collection in 2009 , an aggregate growth of $11.4 \%$, more or less than homogeneous form in the first ten subsectors contributing to the Gross Census Value Added (VACB).

According to data from SECTURJAL (2012), the municipality of Puerto Vallarta and its area of influence receive an average of more than 4 million visitors a year, has 16,000 hotel rooms of tourist category (and continues to increase), which offers a overview of the prospective economic composition of the region:

- The municipality has the seventh international airport in importance nationwide, serving more than 1.3 million passengers, occupying the third place as a beach destination

It is the fourth place in the cruise segment, with more than half a million passengers served annually

- $\quad$ It is the second destination nationwide with timeshare offer, offering more than 80 housing developments under this modality

\section{Availability of natural resources}

According to the Institute of Statistical and Geographic Information (IIEG), in its 2018 report, the municipality of Puerto Vallarta is geographically located in the coastal region of the state of Jalisco. It is surrounded by the municipalities of Cabo Corrientes, Talpa de Allende, Mascota and San Sebastián del Oeste, similarly, it finds a bordering area to the northwest with the state of Nayarit. 
The climatic conditions and the geographical composition of the surface considerably limit the primary production, with the exception of the extraction of rocky and sandy materials, since there is a concentration of $49.1 \%$ of granite in the rocks, in addition to acidic intrusive igneous constituted by quartz , feldspar and plagioclase, mainly.

As for the geographical distribution, $65.8 \%$ of the land has slopes greater than $15^{\circ}$, that is, they are considered mountainous. The composition of the soil is predominantly regosol (49.4\%), so they have a low evolution derived from erosive processes, probably in relation to the climate, which is typified as subhumid, housing minimum annual temperatures of 13.4 and maximum of $31.6^{\circ}$, thus as an average annual rainfall of 1,385 millimeters.

This set of conditions generates a clear soil, poor in organic matter, identifying variable fertility for the agricultural sector, where the cultivation of grains presents moderate results and, the most efficient, forest and livestock use, still has variable yields.

As for the topography, the municipality has a limited flat surface, with most concentrated on the banks of the rivers, although most of the territory is rugged, consisting of rocky, clay and cliff masses, mainly due to the influence of the Sierra Madre Occidental.

The total extension of the municipality is 130,067 hectares, of which 93,468 hectares correspond to forest resources in which exploitable tree species grow, mainly chilte, tampicrán, Brazil tree, amapa, spring, parota, cedar, walnut, fruit trees, among others, but given excessive exploitation, not all are available for economic purposes. The distribution of the remaining area consists of 6,493 hectares destined for agricultural use, 19,700 hectares for livestock use, 1,340 for urban use, 9,068 are typified as another use and, finally, 58 hectares do not have a specified use (Government of the State of Jalisco , 2019). The fauna, on the other hand, is composed of various endemic species, mainly birds, as well as reptiles and mammals, such as deer, tlacuaches, iguanas, garrobos, crocodiles, varieties of snakes, parakeets, macaws, pigeons, among a wide variety that It reaches more than one hundred different species. Similarly, marine fauna is wide and exploitable, such as sierra, dorado, sailfish, snapper, red snapper, garlopa and bonito.

\section{Method}

For the preparation of this research, various sources and resources generating information were analyzed, mainly those provided by official government institutions. The aggregate data offered by the National Institute of Statistics and Geography, as well as those offered by local and state government institutions, are integrated and analyzed.

Finally, a prospective analysis is carried out to determine the main trends offered by the region's environment.

\section{Discussion}

\section{Development perspectives based on the factors analyzed}

The state of Jalisco registers a considerable, drastic and multidimensional growth. This is the result of the constant work carried out on all fronts involved in the development and not only of tangential or consequential aspects of largescale factors, but of consistent developmentbased planning. In 2010, Jalisco concentrated 7.35 million inhabitants, 264,361 economic units, which represented $7.1 \%$ of the national total and employed more than 1.5 million people, equivalent to $7.4 \%$ of the Economically Active Population (PEA) of the national total ; all this as a result of the application of economic policies focused on business development through two basic axes, namely, acceleration and improvement of traditional industry and financing of emerging economies (Ballescá, 2013).

The planning and economic model maintains its continuity through the follow-up of various policies, business development programs and based on the development plan, promoting the formation of business clusters in strategic sectors for the state, such as the tequila production chains, Crafts (furniture, decoration and ceramics), as well as high technology: automotive, educational and software development. Added to the above are strategic guidelines focused on social development, improvement in the quality of life, inclusion and sustainability and care of the environment (Government of the State of Jalisco, 2007). 
The State Development Plan (PED), with a validity to 2033, in accordance with the projects developed and the prospective analysis of the previous points for the state of Jalisco and, consequently, for the municipality of Puerto Vallarta, allows to identify the following perspectives developmental:

$\begin{array}{ll}- & \text { Environment and sustainable life } \\ - & \text { Prosperous and inclusive economy } \\ - & \text { Equal opportunities } \\ - & \text { Guarantee of rights and freedom } \\ - & \text { Reliable and effective institutions }\end{array}$

\section{Environment and sustainable life}

Within the international agenda, welfare has been established since 1990 by the United Nations Organization (UN) as a fundamental indicator for development, the latter understood as multidimensional and focused on the quality of life, and not only as a economic indicator based on the generation of value to GDP. In this way, the Human Development Index (HDI) is generated, which represents a set of indicators in three substantial aspects, namely, per capita income, quality in health services, and changes in educational systems (Government of the State of Jalisco , 2013). Puerto Vallarta, since 2005, has registered an HDI rated as high, around 0.87 , which exceeds the state average, located at 0.82 , excelling in aspects such as life expectancy at birth, literacy, health and average income level by inhabitant (SECTUR, 2014). Within the institutional framework, the municipality of Puerto Vallarta registers a Municipal Development Index (IDM), which stands as "very high", in almost all the items evaluated, such as citizen participation, transparency in public information, institutional functioning, social conditions and environment. This allows us to infer that there is an acceptable level and quality of life within the municipal area; however, the areas of opportunity are presented for the development of proposals that allow to mitigate limiting aspects in this regard, within which they are identified:

- $\quad$ Management and generation of more and better access roads, which implies the development of environmentally friendly construction facilities, as well as focusing on physical links with localities that are not close to economic centers. This condition also has an impact on health issues and the supply of basic supplies.
- Work on the development of strategies, policies and social participation for the diversification of the economy, since the high specialization in tourism generates vulnerability to environmental or economic contingencies

Promote plans, programs and projects with environmental awareness. Economic growth can also create harmful conditions for the environment, such as the growth of the urban area outside the development plan, the lack of basic public services or the spread of diseases. Initiatives that integrate society, private companies, and the three levels of government should be promoted, which implies a considerable effort for its strategic, administrative and operational management, in such a way as to ensure its successful implementation.

\section{Prosperous and inclusive economy}

One of the most relevant transversal dimensions for the development of the regions is the economy. According to the Competitiveness Agendas of the federal government, the economy of Puerto Vallarta changed dramatically and rapidly in the last two decades, going through a transformation - which still persists - from the primary sector to the tertiary sector, mainly towards trade and commerce. offer of tourist services, having repercussions on the territory and the structure of the population (SECTUR, 2014).

Although this condition favors investment and capital management, it faces problems of an accelerated geographical expansion, such as the provision of public services, marginalization, socio-spatial fragmentation and unintended negative effects on the natural environment. At the state level, Jalisco, in the last record of economic activity, presents constant quarterly growth of between $2.1 \%$ and $2.4 \%$ in primary, secondary and tertiary activities throughout the year (Ministry of Economy, 2016). According to the Statistical Yearbook edition 2018, Jalisco is the first place in the production of cattle and poultry production, a model of sustainable logging and presents a considerable economic participation in various sectors and vital economic subbranches for the development of the region, as can be seen in table 3 . 


\begin{tabular}{|c|c|c|}
\hline Sector & $\begin{array}{l}\text { Economic } \\
\text { activity }\end{array}$ & $\begin{array}{l}\text { Indicator } \\
\text { Relative Position }\end{array}$ \\
\hline \multirow[t]{3}{*}{ Primary } & Cattle & $\begin{array}{l}3348965 \text { heads / } \\
\text { main producer }\end{array}$ \\
\hline & Poultry & $\begin{array}{l}78521604 \text { units } \\
\text { main producer }\end{array}$ \\
\hline & Wood production & $\begin{array}{ll}407 \quad 119 & \mathrm{~m} 3 \\
\text { within } & \text { the } \\
\text { average; } & \text { Main: } \\
\text { Pine } & \end{array}$ \\
\hline Secondary & Building & $\begin{array}{l}1122 \text { economic } \\
\text { units / second } \\
\text { national place }\end{array}$ \\
\hline \multirow[t]{2}{*}{ Tertiary } & $\begin{array}{lr}\text { Production } & \text { value } \\
\text { of sales } & \text { of } \\
\text { processed } & \\
\text { products } & \\
\end{array}$ & $\begin{array}{l}405743 \quad 364 \\
\text { thousand pesos } \\
\text { fourth national } \\
\text { place }\end{array}$ \\
\hline & Commerce & $\begin{array}{l}12036 \text { economic } \\
\text { units / / third } \\
\text { national place }\end{array}$ \\
\hline \multirow[t]{2}{*}{$\begin{array}{l}\text { Subrama: } \\
\text { Tourism }\end{array}$} & Lodging & $\begin{array}{l}2,038 \text { economic } \\
\text { units / first } \\
\text { national place }\end{array}$ \\
\hline & Food and drinks & $\begin{array}{l}8025 \text { / national } \\
\text { first place }\end{array}$ \\
\hline
\end{tabular}

Table 3 Main Economic Activities in Jalisco, according to Sector

Source: Statistical and Geographic Yearbook by Federative Entity (2018)

The state grows in these key sectors and manages to generate three strategic axes for the economic development of the entity, namely, management of finance and collection, management of public and private investment, and strengthening of the application of Information Technology and Communications (ICT).

For the best management of government finances at the state level, the government generated a scheme based on the restructuring of policies focused on reducing public spending, mainly for the procurement exercise, as well as those focused on increasing the number of participating economic units in tax collection, in addition to not increasing the tax burden for taxpayers (State Government, 2018).

For the second axis, the increase in investment, both public and private, is promoted. During the past period (2013-2018), more than 799 projects of a public nature were developed in 117 municipalities within the state of Jalisco, adding a total investment of 2,310 million pesos (State Government, 2018). For 2015, Jalisco attracted $8.8 \%$ of direct foreign investment, maintaining, on the other hand, a constant growth rate in relation to exports (see figure 3 ).

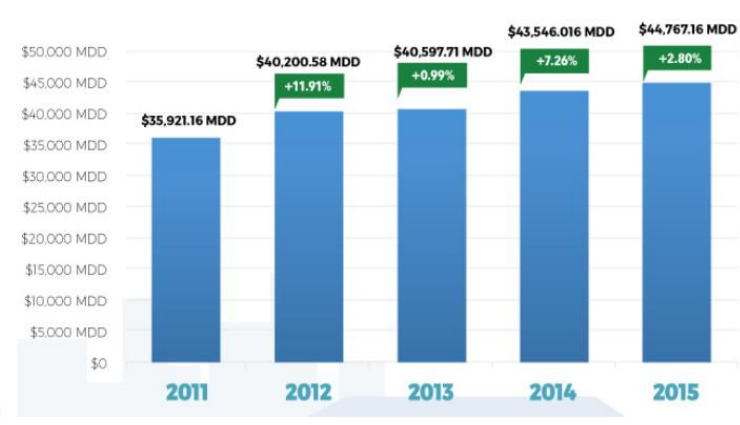

Figure 3 Exports of the state of Jalisco in the last years registered

Source: IIEG (2016)

The last axis, the development of aspects focused on the application of ICT, is multidimensional and was based on implementation within public management. For this purpose, part of the following actions:

Apply technology platforms focused on the transparency of the public administration exercise. In addition to the development of government information portals, the realization of procedures is strengthened through the various platforms presented by the state government, as well as the increase of the information presented to feed the Geographic Information System (GIS) database., in addition to the creation of many other portals focused on the promotion of culture and knowledge International Linking It is based on collaborative management with other countries (Israel, USA and the European Union), in a way that facilitates the development of projects focused on ICT innovation and application, which presents important results and allows identifying areas of opportunity for its improvement, mainly in the promotion of scientific and innovative productivity (see figure 4).

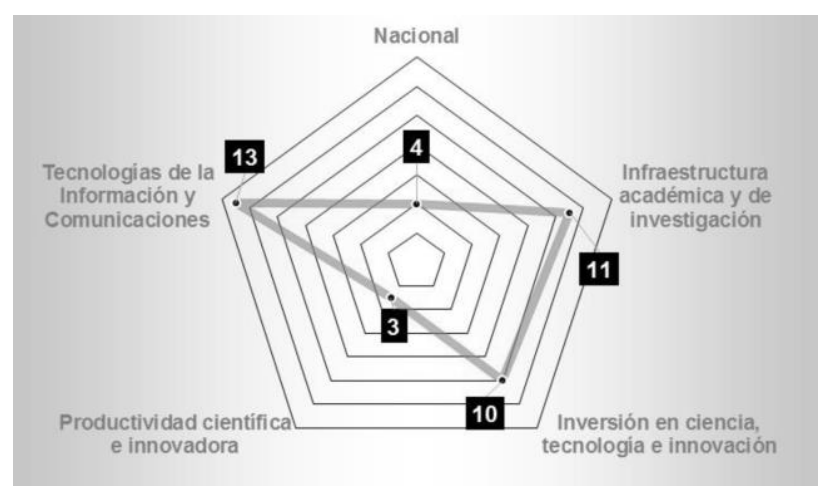

Figure 2 National Ranking of Science, Technology and Innovation 2013: Jalisco

NAVARRO-ALVARADO, Alberto, GONZÁLEZ-MORENO, Cynthia Dinorah and SÁNCHEZ-BELTRÁN, Martha Irene. Evaluation of the Contextual Factors of Puerto Vallarta to Define Graduate Profiles in Higher Education Institutions. Journal of Human Resources Training. 2019 
As can be seen in the above, Jalisco has strong economic subsectors within the three main productive sectors, as well as a considerable and growing mixed investment structure, all this through a technification of public administration and development in various fronts for the application of ICT. However, there are important areas for the development of these aspects, especially for their maintenance and expansion. It addresses the need for a generation of more and better access roads, which directly impacts the distribution and products and geographical links with other municipalities in such a way that the regional economy of the localities can be strengthened. On the other hand, business development and the link between public and private agencies should be promoted, so that mixed investment can generate positive and sustainable results in the long term.

\section{Equal opportunities}

For the generation of a state with opportunities, it is based on the integration of economic factors and the generation of well-being. To this end, public agencies start from the central objective of reducing the imbalance in the regions by offering quality services, which is achieved through the identification of regional vocations, as well as potential factors for development, which must be analyzed from the perspective of sustainability.

In addition to the notion of well-being, promulgated by the UN and the International Labor Organization (ILO), the generation of new jobs must be consistent with the quality of life of citizens. Throughout the entire territory of the state there are still important problems that must be resolved, such as underemployment, low productivity, low pay, among others that, together, generate social vulnerability and poverty (State Government, 2013).

Within the State Development Plan, the following guidelines for work management and project development that allow for fair employment opportunities are contemplated:

Increase and diversify highly employment-generating exports that trigger the creation and consolidation of micro, small and medium enterprises Develop transversal regional investment projects
- $\quad$ Promote formal self-employment and micro-entrepreneurship

- $\quad$ Increase the supply of technicians and professionals based on demand and labor market trends

- Increase investments in economic activities that promote multiplier effects on employment

- Accelerate a capital goods industry with local patents

- Improve the environment and working conditions

- Encourage equal employment opportunities for men and women

Promote the specialization of human capital through the development of its capabilities

The generation of opportunities for all citizens involves the joint work of various agencies, mainly educational ones, although this must be achieved in close collaboration with private companies, as well as with non-profit organizations through comprehensive and transversal projects.

\section{Guarantee of rights and freedom}

In correspondence with the previous aspects, the generation of a state of law leaves the governmental institutions for the full compliance of the law through legality, objectivity, efficiency, professionalism, honesty and respect. The Jalisco State Development Plan is based on various areas of intervention, such as: citizen security, justice and the rule of law, human rights and civil protection.

The achievement of a rule of law that has an inclusive scope in all the dimensions of the individual, both in their work and social practice, which demands the development of proposals with human sense based on the law.

\section{Reliable and effective institutions}

As indicated in the Jalisco State Development Plan, the approaches to economic and social development must be transversal, considering the multiple dimensions that make up society, as well as its needs, always with an inclusive approach and with a view to the conservation of environment. 
Within the municipality of Puerto Vallarta, public institutional performance has been considered as good in almost all its aspects (SECTUR, 2014), although there are considerable areas of improvement, especially in relation to its linkage, participation and development of multilateral projects.

The supply of public education is sufficient and of quality in its different levels of training, although the presence of a considerable higher level educational offer stands out. It has the presence of public and private institutions. The seventh most important university in the country (according to the QS World University Rankings), the University of Guadalajara, is present with a regional university center, as well as an academic unit of the National Technological of Mexico, through the Mario Technological Institute Molina.

Among the general considerations to be developed, it is intended to promote citizen participation, transparency, accountability, among other aspects requested by the Organization for Economic Cooperation and Development (OECD) as a fundamental requirement for the framework of its indicators.

\section{Conclusions}

Currently, Jalisco is ranked as the second federative entity that contributes to the Gross Domestic Product (GDP) at the national level, with $7.1 \%$ (see figure 3). Among the main sectors in high development in the state, are those dedicated to software, use of Information and Communication Technologies, as well as the expansion of manufacturing, processing, marketing and service industries, which represents various opportunities in all areas of training offered by the Mario Molina Institute of Technology (ITMM).

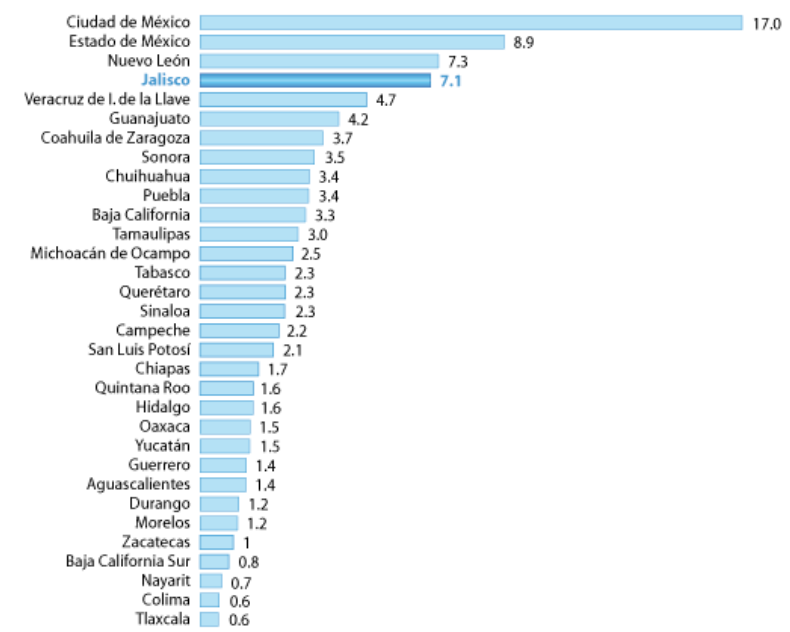

Figure 3 GDP by federative entity

Contribution to the Gross Domestic Product (GDP), by federative entity. Source: INEGI-National Accounts of Mexico (2016).

In contrast to the economic development recorded in recent periods, the agendas of international organizations (such as the OECD, ILO, UN, among others), within the local, regional and national context, various disciplinary issues that will be necessary for the attention to current and emerging problems. These training areas have a transdisciplinary and multidisciplinary nature, so the educational offer should provide for the attention of these points of interest for the resolution of problems from various dimensions.

The Mario Molina Technological Institute (ITMM), in its Puerto Vallarta Campus has the following educational offer ${ }^{1}$ :

- $\quad$ Bussines managment's engineering

- $\quad$ Electromechanical Engineering

- $\quad$ Computerstystems engineer

- Information Technology Engineering

- Gastronomy

- $\quad$ Bachelor of Tourism

- Architecture

\footnotetext{
${ }^{1}$ Para mayor referencia, se recomienda consultar el portal oficial de la institución: http://www.tecvallarta.edu.mx 


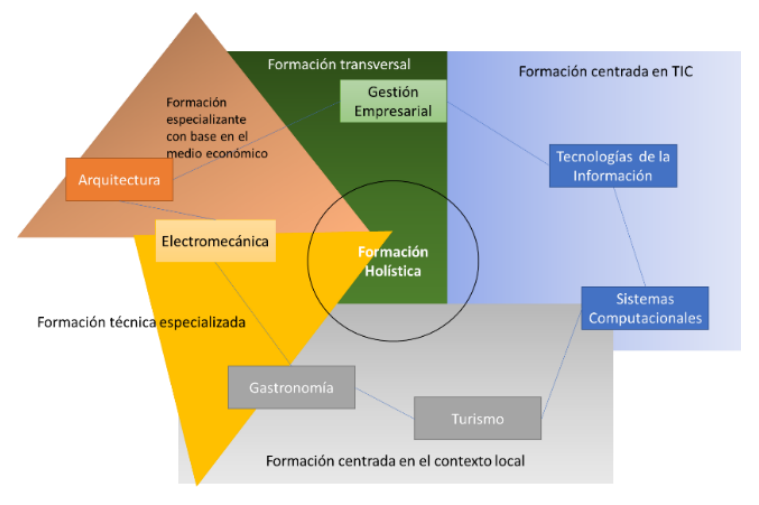

Figure 4 ITMM training areas

Training areas based on the academic offer of the Mario Molina Technological Institute in the intervention area. Source: Own construction based on grid diagnosis.

The current academic offer of the ITMM, Puerto Vallarta Campus, is constantly updated, not only based on the needs of the environment, but considering different social, economic, academic and educational dimensions through various prospective analyzes. In 2009, anticipating the needs of eclectic training programs that could meet the demands of highly trained human resources of business organizations in their area of influence and of the regional context, business management engineering is offered, which trains capable professionals to offer integral solutions to companies that are in diverse processes of growth, expansion and, in some cases, generation of new businesses.

In addition, the ITMM ${ }^{2}$, generates, in the same period, the first higher education program focused on the exploitation of cultural resources, such as gastronomy. This program undergoes constant adaptations and updates derived from the constant research and innovation of such a program until it becomes the Bachelor's Degree in Gastronomy. It was intended, among many other objectives, to supply the local demand for highly competent human resources in the food and beverage business sub-range, capable not only of managing its operation, but of promoting the intangible resources of the organization.
To this initiative is added the Bachelor of Tourism program, which is of recent offer and aims to meet the demand for tourism services from a different, non-traditional approach, with a strong focus on sustainability, generating innovative options and, mainly, addressing the increasing demand in this subsector.

The Bachelor of Tourism offered by the ITMM, Puerto Vallarta Campus, is based on an integral, holistic and multidisciplinary approach. This career addresses a large part of the global trend initiatives that demand special attention, such as environmental care, multiple tourist services, care and preservation of culture as a tourist attraction, regional capacities for the generation of alternative tourism, among others, attending, in this way, the needs of the local, regional and national environment.

One of the main axes for the development of the state of Jalisco is the participation in the application of Information and Communication Technologies, which has been a strategic line involved in the plans for the development of the entity. The ITMM maintains its constant offer of careers in this area, such as Computer Systems Engineering, which trains professionals in cutting-edge issues for the use of computer equipment and software development in various platforms and languages, from business teams, to those dedicated at leisure.

To complement the computer systems approach, a fundamental perspective for any economy, the offer of Information Technology Engineering is presented, which seeks to offer integral solutions for companies in terms of connectivity, Internet, network structuring, database administration. data, computer security, among many other avant-garde issues that are currently a concern, as well as all those implications that may represent a challenge for the future.

\footnotetext{
2 En su momento denominado Instituto Tecnológico Superior de Puerto Vallarta. 
Finally, two specialty careers are offered that meet particular demands for the maintenance of local needs, but from a universal training perspective. In the first place, there is the Architecture career, which is born from the rapid growth registered in the region during the last two decades, a phenomenon that still persists and maintains a constant demand for services of this nature; however, constant updates have been made to the study programs to train professionals with better capacities in the design not only of living spaces, but also functional, environmentally friendly, as well as based on the application of new technologies.

On the other hand, the Electromechanical Engineering race is offered, which maintains a constant performance area in various training areas, mainly for the development of maintenance services, design of electrical and mechanical systems, among others. In spite of being a specialty career, it presents a broad spectrum for job performance, in addition to being within the technological and development field, which represents a fundamental opportunity for the generation of knowledge and intellectual property.

The municipality of Puerto Vallarta is located as one of the main tourist destinations for the state of Jalisco, in addition to having a prominent location geographically with other states, such as Nayarit, with whom a collaborative relationship is maintained given the bay that It is shared, so the influence of the ITMM graduates, Puerto Vallarta campus, participate in the labor market that makes up the Banderas Bay area.

Public and private business organizations are identified mainly in the tourism subsector, as well as the services associated with it, such as maintenance services, advice, training, human resources training, logistics and distribution, leisure companies, adventure tourism, construction, among many others.

Puerto Vallarta offers an environment of constant growth, as presented in previous sections, which allows taking advantage of the economic position of the state of Jalisco. In this way and, considering the academic offer and regional needs, the following professional needs for the environment can be identified:
Business
Management
and
Entrepreneurship
- Understand the technological trends for the implementation of ICT in business organizations
- Evaluate productive processes for business organizations
- Diagnose the intrinsic and extrinsic contextual conditions of organizations
- Generate conditions for the operation of business through the coordination of various processes
- Recognize business competencies based on their organizational structure
- Integrate organizational components through legal, functional, operational, human, economic and social dimensions

- Tourism and diversification for the tourist offer

- Design customer-oriented service processes

- Understand the integration of computer systems within organizations that offer tourism services

- Establish communication and information systems based on emerging technologies

- Analyze the global context to understand the trends of global change in recreational services

- Develop skills focused on flexibility, innovation and integration of technology in organizations that offer tourism services

- Technological development and ICT applications

- Analyze the human implications for insertion in the age of knowledge

- Identify knowledge trends and their technological applications

- Apply the existing technologies of the various branches of knowledge for the development of new technologies

- Develop technological equipment focused on the present and future needs of the modern human being 
- Associate technological development with the various human dimensions for sustainable use

- Integrate environmental and sustainable perspectives to the development of new technologies

\section{References}

Albano, S. (2016). Consultores, empresarios, herramientas de gestión y vinculación con responsabilidad social. Ciencia, Docencia y Tecnología, Vol. 27, No. 53, pp. 162-204.

Anuario Estadístico y Geográfico por Entidad Federativa (2018). INEGI.

Asociación de Hoteles y Moteles de Puerto Vallarta y Bahía de Banderas (2019). Consulta de su portal oficial desde: http://www.vallartahoteles.com, con acceso en abril de 2019.

Ayuntamiento de Puerto Vallarta (2019). Medio físico del municipio de Puerto Vallarta. Consulta de su portal oficial desde: https://www.puertovallarta.gob.mx/2018-

2021/Ciudad/localizacion.php, con acceso en abril de 2019.

Ballescá, M. (Coord.) (2013). Desarrollo Económico de Jalisco: Retrospectivas y Retos. Guadalajara: Secretaría General de Gobierno.

CANACO-SERVITUR (2019). Cámara Nacional de Comercio, Turismo y Servicios de Puerto Vallarta. Consulta de su portal oficial desde: http://canacovallarta.com, con acceso en abril de 2019.

Cano, G. (2018) Las TIC en las empresas: evolución de tecnología y cambio estructura en las organizaciones. Dominio de las Ciencias, Vol. 4, No. 1, pp. 499-510.

Chamorro, A. y Tato, J. (2005). Globalización y competitividad en las empresas: los recursos humanos. Análisis Económico, Vol. 20, No. 43, pp. 167-186.

DENUE. Sistema informático y estadístico del Instituto de Información Estadística y Geográfica. Disponible desde: http://www.beta.inegi.org.mx/app/mapa/denue/, con acceso en abril de 2019
García, D. (18 de octubre de 2018). Sector servicios supera crecimiento en economía. Milenio. Disponible desde: https://www.milenio.com/negocios/sectorservicios-supera-crecimiento-en-economia, con acceso en abril de 2019

García, F. y Cordero, A. (2009). Nuevas formas organizativas adoptadas por dos grupos de empresas de México

Gobierno del Estado de Jalisco (2007). Plan Estatal de Desarrollo, Jalisco 2030. Guadalajara: Secretaría de Planeación.

Gobierno del Estado de Jalisco (2013). Plan Estatal de Desarrollo Jalisco 2013-2033: Un plan de todos para un futuro compartido. Guadalajara: Dirección de Publicaciones del Gobierno del Estado de Jalisco.

Gobierno del Estado de Jalisco (2018). Sexto Informe de Gobierno: Tomo I. Secretaría de Planeación, Administración y Finanzas.

Gobierno del Estado de Jalisco (2019). Municipios de Jalisco: Puerto Vallarta. Consultado desde: https://www.jalisco.gob.mx/es/jalisco/municipi os/puerto-vallarta, con acceso en abril de 2019.

Instituto de Información Estadística y Geográfica. (2011). Censo Nacional de Población y Vivienda 2010. México: INEGI.

Instituto de Información Estadística y Geográfica. (2018). Diagnóstico Municipal de Puerto Vallarta. México: IIEG

Ojeda, R. y Jiménez, O. (2011). Responsabilidad Social Empresarial, en el sector servicios de Mérida, Yucatán. Tec Empresarial, Vol. 5, No. 3, pp. 37-48.

Organización de las Naciones Unidas (ONU) (1990). Programa de las Naciones Unidas para el Desarrollo. Bogotá: Tercer Mundo Editores.

Organización de las Naciones Unidas (ONU) (2018). Situación y perspectivas de la economía mundial 2018. Naciones Unidas: Departamento de Asuntos Económicos y Sociales.

Red de Asociaciones Altruistas, Puerto Vallarta y Bahía de Banderas. Consulta realizada a su portal oficial desde: https://redaltruista.org, con acceso de abril de 2019.

NAVARRO-ALVARADO, Alberto, GONZÁLEZ-MORENO, Cynthia Dinorah and SÁNCHEZ-BELTRÁN, Martha Irene. Evaluation of the Contextual Factors of Puerto Vallarta to Define Graduate Profiles in Higher Education Institutions. Journal of Human Resources Training. 2019 
PuertoVallarta.net. Portal oficial de orientación turística. Consulta desde: https://www.puertovallarta.net/espanol/, con acceso en abril de 2019.

Secretaría de Economía (2016). Información Económica y Estatal: Jalisco.

SECTUR (2014). Agendas de competitividad de los destinos turísticos de México: Puerto Vallarta. Gobierno del Estado de Jalisco.

SECTURJAL (2019). Secretaría de Turismo del Estado de Jalisco. Portal virtual: https://secturjal.jalisco.gob.mx, con acceso en abril de 2019. 